porn, which is cited. Finally Nead argues that the new media and new visual technologies of the $1990 \mathrm{~s}$ must not be ignored by feminists. New producers of and audiences for images are emerging. Men are no longer the sole arbiters of images of female desire and pleasure. The important question is who has the power of representation, of definition, and of delineation around the female nude. No one could argue with Lynda Nead's conclusion that we must ensure that women also decide what is pleasurable and exciting in the new visual technologies. But whether they will provide more space for feminist voices and images, as she asserts, remains to be seen.

\section{Caroline Evans}

\section{References}

BARTHES, Roland (1976) The Pleasure of the Text trans. R. Miller, London: Jonathan Cape.

BOURDIEU, Pierre (1984) Distinction: a Social Critique of the Judgement of Taste trans. Richard Nice, London and New York: Routledge \& Kegan Paul.

BUTLER, Judith (1990) 'Gender trouble, feminist theory and psychoanalytic discourse' in Feminism/Postmodernism L. J. Nicholson (editor), New York and London: Routledge, 324-40.

EAGLETON, Terry (1993) 'Body Work by Peter Brooks' Times Literary Supplement Vol. 15, No. 10, 27 May.

MERLEAU-PONTY, M. (1962) Phenomenology of Perception trans. C. Smith, New York: Humanities Press.

SONTAG, Susan (1984) Against Interpretation and Other Essays London: Andre Deutsch.

williaMS, Linda (1990) Hard Core: Power, Pleasure and the 'Frenzy of the Visible' London: Pandora.

\section{Contemporary Feminist Theatres: to Each her Own}

\section{Lizbeth Goodman}

London: Routledge 1993,

ISBN 0415073065 , £11.99 Pbk, ISBN $0415073057, £ 35.00 \mathrm{Hbk}$

Since Michelene Wandor's Carry on Understudies was published in 1986, there have been few books which bring together the almost nonexistent coverage of contemporary feminist theatres. From an academic point of view, disparate information about the recent history, theories and practices of feminist theatres has had to be gleaned from a wide range of often ephemeral sources such as articles, chapters, papers and even word-ofmouth, frequently deriving from cultural, literary and film criticism rather than the specifically theatrerelated, and although the author has extensively and generously acknowledged the pioneering work done by other writers, there continues to be a constant cry for work which begins to bring some of these concerns together. Equally, there is a need to valorize the experiences of feminist theatre practitioners: writers, directors, performers and designers, whose work and ideas are by their nature marginalized or lost through a lack of authorization. In this detailed and meticulous book Lizbeth Goodman sets out to achieve both these tasks, and the eagerness with which her book has been pounced on by women working in theatre and particularly academia is a clear indication of such needs. However, as is generally the case with desires, fulfilment is not always entirely achieved.

The book is concerned specifically with political theatre oriented toward change; a history of British 'feminist' rather than 'women's' theatre produced since 1968. This strategy means that forms of theatre practice and critical approaches developing from psychoanalytic, poststructuralist or postmodern theories, and particularly those of the French feminists, have been necessarily but sadly omitted, although the book does set out to address cultural contexts and informing performance theories as well as their differences and similarities in theatre and societal practices. 
The book is extremely wellorganized with self-contained chapters and sections which are not developmental, but which frequently cross-reference where necessary (and sometimes, frustratingly, do not). The reasons for the organization of the eight broad chapter headings are clearly set out in the Introduction. The positive aspect of this organizational strategy means that the book is excellent for 'dipping into' for particular information, and, indeed I was able immediately to recommend the section on the representation of Black women in contemporary theatres to a student who is working on precisely that topic. However, because the book is so painstakingly researched and brings together a great deal of information rather than innovative concepts or ideas, it is difficult to read it right through, although the extensive Introduction and the thoughtful Conclusion which seeks new definitions for the 'ambiguous identities' of feminist theatres provide a strong structural framework.

Within that framework however, there are some apparent, and perhaps inevitable, inconsistencies. Although the strategies and parameters are clearly set out and most chapters focus exclusively on the social, historical or contextual, the chapter on lesbian theatres is specifically theoretical, applying some of the ideas from feminist film and literary criticism (based on Laura Mulvey's theory of the male gaze), to the culturally produced image of 'the feminine' and exploring the construction of the lesbian spectator in theatre. This theorizing of the spectator was rather at odds with other explorations of audience in the book which were almost entirely sociological. Lizbeth Goodman laments the lack of any comprehensive genderand/or ethnicity-specific audience survey but, in the manner which is adopted throughout the book, she collects together a wide range of useful and otherwise disparate information.

This need to encompass information and ideas means that there is also a collapsing of theoretical notions of authorship with the concrete problem of whose name should appear on published materials, particularly for plays or performances which have been collectively devised and written.

The advantage of such exhaustive coverage, however, is that much of the work done in and by feminist theatre(s) in Britain is recorded and is supported by an excellent bibliography which indicates extensive riches for further reading; the painstaking research done by Lizbeth Goodman offers the reader a history of the struggles and achievements of a wide spectrum of women engaged in the representation(s) of self in feminist theatre since 1968. Lizbeth Goodman also moves towards a 'new theory' for feminist theatre(s) which aims to take account of aesthetic and political considerations within the diversity and range of practices described in the book. Although she proposes a more 'practical' approach than the 'new poetics' suggested by Sue-Ellen Case (Case, 1988:112), they are both arguing for a flexible theory which encompasses a dialectical relationship between theory and practice.

This is a hugely useful book, filling in many gaps, and students in particular will find it a rich resource and a sound introduction to further study. Practitioners and academics alike will find in its range of detail an informative account of often unrecorded recent feminist theatre histories.

\section{Sue Smith}

\section{Reference}

CASE, Sue-Ellen (1988) Feminism and Theatre London: Macmillan. 